JPPKMI 2 (1) (2021) 11-16
JURNAL PENELITIAN DAN PENGEMBANGAN
KESEHATAN MASYARAKAT INDONESIA
Jttps://journal.unnes.ac.id/sju/index.php/jppkmi

\title{
Iklim Kerja, Postur Kerja, dan Masa Kerja Terhadap Kelelahan Kerja pada Pekerja Bengkel Las
}

\author{
Nurul Fidinia Hijah ${ }^{1} \bowtie$, Yuliani Setyaningsih ${ }^{1}$, Siswi Jayanti ${ }^{1}$ \\ ${ }^{1}$ Bagian Keselamatan dan Kesehatan Kerja, Fakultas Kesehatan Masyarakat, Universitas Diponegoro, Indonesia
}

\section{Info Artikel}

Sejarah Artikel:

Diterima 17 April 2021

Disetujui 8 Juni 2021

Dipublikasi 15 Juni 2021

\section{Keywords:}

Fatigue, Work Climate, Work Posture, Working Period

URL:

https://iournal.unnes.ac.i d/sju/index.php/ippkmi /article/view/47282

\begin{abstract}
Abstrak
Kelelahan kerja merupakan suatu keadaan yang dirasakan oleh tenaga kerja dan dapat menimbulkan penurunan vitalitas dan produktivitas kerja. Kelelahan kerja bisa terjadi karena beberapa faktor diantaranya iklim kerja, postur kerja dan masa kerja. Salah satu pekerjaan yang terpapar iklim kerja adalah pekerjaan di bengkel las. Penelitian ini bertujuan untuk menganalisis hubungan iklim kerja, postur kerja dan masa kerja terhadap kelelahan kerja pada pekerja bengkel las. Variabel bebas berupa iklim kerja, postur kerja serta masa kerja dan dilakukan dengan menggunakan metode penelitian kuantitatif pendekatan cross sectional. Teknik pengambilan sampel yang digunakan adalah simple random sampling. Sampel pada penelitian yaitu berjumlah 75 pekerja dan dianalisis menggunakan Uji Chi-Square tingkat kepercayaan 95\%. Hasil menunjukkan variabel iklim kerja berhubungan terhadap kelelahan kerja dengan nilai $p=0,041$, variabel postur kerja berhubungan terhadap kelelahan kerja dengan nilai $p=0,027$, dan variabel masa kerja berhubungan terhadap kelelahan kerja dengan nilai $p=0,000$. Kesimpulan bahwa iklim kerja, postur kerja dan masa kerja berhubungan dengan kelelahan kerja pada pekerja bengkel las.
\end{abstract}

\section{Abstract}

Fatigue is a condition that is felt by the workforce and can lead to a decrease in vitality and work productivity. Fatigue can occur due to several factors including work climate, work posture and working period. One of the jobs exposed to the work climate is work in welding workshop. This study aims to analyze the relationship of work climate, work posture and working period to fatigue in welding workers. Independent variables are work climate, work posture and work period using quantitative research methods with cross sectional. The sampling used is simple random sampling. The sample is amounted to 75 workers and analyzed using Chi-Square Test with $95 \%$ confidence. Work climate variable is related to work fatigue with $p$ Value $=0.041$, the work posture variable is related to work fatigue with $p$ Value $=0.027$, and the variable period of work is related to work fatigue with $p$ Value $=0.000$. Work climate, work posture and working period are related to work fatigue in welding workers.

Alamat korespondensi:

J1. Prof. Soedarto No.1269, Tembalang, Kec. Tembalang,

Semarang, Jawa Tengah 50275

E-mail: nurulfidinia35@gmail.com 


\section{PENDAHULUAN}

Kelelahan kerja merupakan masalah serius yang harus mendapatkan perhatian. Hal ini dibuktikan dengan data dari International Labour Organization (ILO) pada tahun 2013 mengatakan bahwa hampir setiap tahun sebanyak dua juta pekerja meninggal karena kecelakaan kerja akibat faktor kelelahan kerja. Kelelahan adalah efek yang sering dirasakan oleh setiap individu. Sakit kepala, ketegangan, nyeri sendi, suasana hati yang tidak bagus merupakan sebagian hal yang dirasakan saat terjadi kelelahan (Hockey, 2013). Penyebab kelelahan sangat bervariasi diantaranya ialah dipengaruhi beban kerja, lingkungan kerja, problem fisik dan kondisi kesehatan. Semua keadaan yang ada di sekitar tempat kerja seperti temperatur, kelembaban udara, sirkulasi udara, pencahayaan, kebisingan, getaran mekanis, baubauan, warna dan lain-lain yang berpengaruh terhadap hasil kerja manusia disebut kondisi lingkungan kerja. Kondisi lingkungan kerja yang tidak memenuhi ketentuan keselamatan dan kesehatan kerja (K3) dapat menjadi penyebab risiko bahaya untuk tenaga kerja (Tarwaka, 2010).

Kondisi lingkungan kerja yang begitu panas dapat menyebabkan pekerja merasa tidak nyaman dan dapat membuat badan menjadi lemas karena energi yang terkuras untuk adaptasi dengan suhu ruangan. Akibat lain dari suhu udara yang panas bisa menyebabkan berkurangnya kinerja dan hal ini bisa berkurang drastis dapat terjadi pada suhu $>32^{\circ} \mathrm{C}$, keterampilan berkurang, dan mengganggu koordinasi syaraf sensoris (Setyaningsih $\mathrm{Y}$, 2018). Begitu juga dengan kebisingan yang berpengaruh pada kesehatan kerja dan menimbulkan beban tambahan bagi pekerja. Selain faktor lingkungan, faktor perilaku seperti postur kerja juga dapat menimbulkan kelelahan. Postur tubuh yang janggal dalam jangka lama dapat menyebabkan terjadinya kelelahan dan ketidaknyamanan (Sulaiman, 2018). Dalam salah satu studi menjelaskan bahwa ada beberapa faktor yang menyebabkan kelelahan, seperti masa kerja, umur, dan status nutrisi.
Selain itu kebisingan, iklim kerja dan pencahayaan menjadi faktor penyebab kelelahan. Selain itu pekerja yang bekerja dengan postur kerja yang tidak ergonomis maka pekerja tersebut rentan mengalami kelelahan kerja (Susihono, 2012).

Pengelasan merupakan pekerjaan dimana pekerja akan sering terpapar kebisingan, menerima sumber panas yang bisa berasal dari mesin las dan juga sinar matahari yang langsung mengenai pekerja karena beberapa pekerja melakukan pengelasan di tempat terbuka. Dengan kondisi lingkungan fisik yang seperti itu maka besar kemungkinan pekerja di bengkel las cepat mengalami kelelahan kerja. Hasil studi pendahuluan menunjukkan bahwa pekerja bengkel las bekerja selama 8 jam namun pekerja sering melakukan pekerjaan diluar jam kerja tersebut. Seperti bekerja sampai tengah malam. Pekerja juga cenderung bekerja pada lingkungan fisik yang tidak nyaman seperti iklim kerja yang melebihin NAB yang bersumber dari alat pengelasan dan sinar matahari, bising dan debu. Proses kerja di bengkel las ialah pemotongan besi, pemanasan, penggerindaan, penyambungan, pengecatan hingga pengamplasan hampir semua dilakukan dengan posisi duduk jongkok dan membungkuk. Berdasarkan uraian tersebut peneliti tertarik melakukan penelitian tentang hubungan antara iklim kerja, postur kerja, dan masa kerja terhadap kelelahan kerja pada pekerja bengkel las di Lingkungan Getap Barat Kota Mataram. Tujuan dari penelitian ini untuk menganalisis hubungan iklim kerja, postur kerja, dan masa kerja terhadap kelelahan kerja pada pekerja bengkel las di Lingkungan Getap Barat Kota Mataram.

\section{METODE}

Desain penelitian ini menggunakan penelitian kuantitatif dengan metode analitik observasional dan menggunakan pendekatan cross sectional. Penelitian ini dilaksanakan pada bulan April 2021 di RT 1 dan RT 2 Lingkungan Getap Barat Kota Mataram. Variabel bebas dalam penelitian ini adalah iklim kerja, postur 
kerja, dan masa kerja sedangkan variabel terikatnya adalah kelelahan kerja. Sampel yang digunakan dalam penelitian ini adalah 75 pekerja bengkel las Lingkungan Getap Kota Mataram dengan menggunakan teknik pengambilan simple random sampling . Iklim kerja diukur dengan Questemp 34, postur kerja diukur menggunakan lembar REBA serta kuesioner untuk memperoleh data diri dan masa kerja. Sedangkan pengukuran kelelahan kerja menggunakan aplikasi Reaction Timer. Uji ChiSquare digunakkan untuk menganalisis iklim kerja, postur kerja dan masa kerja.

\section{HASIL DAN PEMBAHASAN}

Responden penelitian adalah pekerja bengkel las di Lingkungan Getap Barat sebanyak 75 orang. Karakteristik responden dapat dilihat pada tabel 1.

Iklim kerja adalah perpaduan suhu, kecepatan gerakan udara, kelembaban serta panas radiasi dengan tingkat pengeluaran panas yang dihasilkan dari tubuh pekerja tersebut akibat dari pekerjaannya. Pada tabel 2 diketahui bahwa sebanyak 18 pekerja (45\%) mengalami kelelahan kerja kategori berat melakukan pengelasan pada iklim kerja dengan suhu lebih dari NAB dengan rata-rata suhu pada semua

Tabel 1. Distribusi karakteristik responden pekerja bengkel las di Lingkungan Getap Barat 2021

\begin{tabular}{|c|c|c|c|}
\hline Variabel & Kategori & Jumlah & $(\%)$ \\
\hline \multirow[t]{2}{*}{ Usia } & $\begin{array}{l}\text { Tua }(>25 \\
\text { tahun) }\end{array}$ & 51 & 68,0 \\
\hline & $\begin{array}{l}\text { Muda } \\
\text { tahun) }\end{array}$ & 24 & 32,0 \\
\hline \multirow[t]{3}{*}{ Status Gizi } & Kurus $(<18,5)$ & 11 & 14,7 \\
\hline & $\begin{array}{l}\text { Normal }(18,5- \\
22,9)\end{array}$ & 51 & 68,0 \\
\hline & $\begin{array}{l}\text { Gemuk } \\
24,9)\end{array}$ & 13 & 17,3 \\
\hline \multirow{5}{*}{$\begin{array}{l}\text { Kebiasaan } \\
\text { Merokok }\end{array}$} & Tidak & 18 & 24,0 \\
\hline & Merokok & & \\
\hline & $\begin{array}{l}\text { Perokok } \\
\text { ringan (1-4) }\end{array}$ & 11 & 14,7 \\
\hline & $\begin{array}{l}\text { Perokok } \\
\text { sedang }(5-14)\end{array}$ & 32 & 42,7 \\
\hline & $\begin{array}{l}\text { Perokok berat } \\
\text { (15) }\end{array}$ & 14 & 18,7 \\
\hline
\end{tabular}

bengkel $30,5-33,8^{\circ} \mathrm{C}$ dan diperoleh kesimpulan bahwa ada hubungan antara iklim kerja dengan kelelahan kerja. Hal ini dapat terjadi karena pekerja terpapar panas baik dari mesin las maupun dari iklim kerja. Selain itu beberapa bengkel las menggunakan penutup/naungan berupa seng yang mana daya serap akan sinar matahari tinggi sehingga suasanya di iklim kerja di bengkel las semakin panas. Dan saat dilakukan wawancara dan observasi, pekerja mengeluarkan keringat yang cukup banyak dan memaparkan bahwa lebih suka minuman berwarna dan bersoda saat sedang istirahat ditambah juga bengkel las tidak menyediakan air minum bagi pekerja. Padahal sejatinya pada saat tubuh mengeluarkan keringat ditambah dengan suhu yang panas maka tubuh membutuhkan cairan elektrolit untuk mengganti garam natrium yang hilang.

Hasil penelitian ini sesuai dengan penelitian terdahulu yang dilakukan pada pekerja di Area Repair Container di PT. X didapatkan nilai signifikansi sebesar 0,000 . Dimana dalam penelitian dilakukan pengukuran iklim kerja sebanyak tiga kali dan dijelaskan bahwa pekerja melakukan pekerjaan salah satunya adalah pengelasan di luar/ruangan terbuka dan terpapar panas sinar matahari langsung serta terdapat keluhan dari pekerja bahwa lingkungan sekitar yang dirasa panas (Kartika M, 2014).

Penelitian ini tidak sejalan dengan penelitian dahulu yang dilakukan pada pekerjaan pengukuran tanah. Penelitian tersebut dilakukan pada mahasiswa yang melakukan pekerjaan pengukuran tanah menggunakan alat teodolit dengan nilai signifikasi sebesar 0,706 yang berarti tidak ada hubungan antara iklim kerja dengan kelelahan kerja. Apabila suhu udara lebih panas pekerja cenderung lebih cepat mengalami kantuk, konsentrasi menurun, dan mudah tersulut emosi (Starizky O, 2016). Untuk menyeimbangkan suhu tubuh dengan lingkungan, maka tubuh akan berusaha mengeluarkan panas dari tubuh ke lingkungan sekitar melalui kulit dengan cara konduksi, konveksi radiasi, dan evaporasi.

Iklim kerja yang panas menyebabkan 
Tabel 2. Tabel silang Distribusi Frekuensi Iklim Kerja, Postur Kerja dan Masa Kerja dengan Kelelahan Kerja pada Pekerja Bengkel Las di Lingkungan Getap Barat 2021

\begin{tabular}{|c|c|c|c|c|c|c|c|c|c|}
\hline \multirow[t]{3}{*}{ Variabel } & \multicolumn{6}{|c|}{ Kelelahan Kerja } & & & \multirow{3}{*}{ P-Value } \\
\hline & \multicolumn{2}{|c|}{ Berat } & \multicolumn{2}{|c|}{ Sedang } & \multicolumn{2}{|c|}{ Ringan } & \multicolumn{2}{|c|}{ Total } & \\
\hline & $\mathrm{N}$ & $\%$ & $\mathrm{~N}$ & $\%$ & $\mathrm{~N}$ & $\%$ & $\mathrm{~N}$ & $\%$ & \\
\hline \multicolumn{10}{|l|}{ Iklim Kerja } \\
\hline $\begin{array}{l}\text { 1. Suhu lebih dari } \\
\text { NAB }\end{array}$ & 18 & 45 & 12 & 30 & 10 & 25 & 40 & 100 & \multirow[t]{2}{*}{0,041} \\
\hline $\begin{array}{l}\text { 2. Suhu Sesuai NAB } \\
\text { Postur Kerja }\end{array}$ & 5 & 14,2 & 15 & 42,8 & 15 & 42,8 & 35 & 100 & \\
\hline 1. Risiko Tinggi & 12 & 40 & 11 & 36,6 & 7 & 23,3 & 30 & 100 & \multirow{3}{*}{0,027} \\
\hline 2. Risiko Sedang & 8 & 36,3 & 7 & 33,3 & 7 & 33,3 & 22 & 100 & \\
\hline $\begin{array}{l}\text { 3. Risiko Rendah } \\
\text { Masa Kerja }\end{array}$ & 6 & 26 & 8 & 34,7 & 9 & 39,1 & 23 & 100 & \\
\hline 1. $>5$ tahun (Lama) & 31 & 63,3 & 17 & 34,7 & 1 & 2 & 49 & 100 & \multirow[t]{2}{*}{0,000} \\
\hline 2. $\leq 5$ tahun $($ Baru $)$ & 6 & 23,1 & 9 & 34,6 & 11 & 42,3 & 26 & 100 & \\
\hline
\end{tabular}

suhu tubuh meningkat sehingga proses pengeluaran keringat yang berlebihan dapat menyebabkan tubuh mengalami dehidrasi dan kekurangan cairan serta garam nutrium, sehingga tubuh akan cepat mengalami kelelahan. Perubahan iklim/cuaca di lingkungan tempat kerja telah menyebabkan terjadinya tekanan panas (heat stress) yang akan diterima oleh tenaga kerja yang bekerja di lingkungan tempat kerja tersebut sebagai beban panas tambahan (di samping beban panas yang dihasilkan tubuh sebagai akibat pelaksanaan kerja), yang dapat mengakibatkan banyak pengaruh negatif kepada tenaga kerja baik yang berupa gangguan pekerjaan (pelaksanaan kerja) maupun gangguan kesehatan (Soeripto, 2008). Suhu panas dapat dikendalikan secara teknis yaitu seperti isolasi sumber panas, insulation/pembalutan, pelindung radiasi, ventilasi, dan pendinginan ruang kerja (Setyaningsih Y, 2018). Untuk meminimalisir terjadinya kelelahan akibat iklim yang melebihi NAB dan bisa mengakibatkan heat stress maka pengelola dapat menyediakan air minum di tempat kerja di tempat yang strategis dan mudah dijangkau pekerja.

Postur kerja bisa diartikan sebagai titik penentu dalam menilai keefektifan pekerjaan. Hasil dari suatu pekerjaan akan baik jika postur kerja yang dilaksanakan telah baik dan ergonomis, karena postur tubuh yang janggal dalam jangka pendek dapat mengakibatkan kelelahan. Postur tubuh janggal merupakan posisi kerja yang salah atau menyimpang dari posisi normalnya saat melakukan pekerjaannya. Dari hasil analisis pada tabel diketahui bahwa pekerja dengan postur kerja risiko tinggi mengalami kelelahan kerja kategori berat sebanyak 12 orang $(40 \%)$ dan dapat disimpulkan bahwa ada hubungan antara postur kerja dengan kelelahan kerja. Penelitian ini sesuai dengan penelitian yang dilakukan di PT. Terminal Peti Kemas Semarang menunjukkan dimana dilakukan pengukuran postur kerja pada operator container crane dengan nilai signifikasi sebesar 0,0001 yang berarti ada hubungan antara postur kerja dengan kelelahan kerja. Hal ini sesuai dengan teori yang menyatakan bahwa sikap kerja yang tidak serasi akan menyebabkan nyeri otot-otot rangka sehingga menyebabkan kelelahan (Amalia NR, 2017).

Postur tubuh yang statis seperti terlalu lama seperti menunduk sangat berisiko menyebabkan keluhan kesehatan, kurangnya relaksasi atau peregangan otot saat bekerja dapat menyebabkan penimbunan asam laktat pada otot yang memicu timbulnya kelelahan. Hasil perbandingan antara kerja otot statis dan dinamis pada kondisi yang hampir sama, dihasilkan bahwa kerja otot statis mempunyai konsumsi energi lebih tinggi, denyut nadi meningkat, dan diperlukan waktu istirahat yang lebih lama (Guyton, 1994).

Posisi tubuh dalam kerja sangat ditentukan oleh jenis pekerjaan yang berbedabeda terhadap tubuh. Masing-masing posisi 
kerja memiliki pengaruh yang berbeda-beda terhadap tubuh. Postur tubuh yang janggal/tidak normal ini juga dapat menyebabkan terjadinya low back pain. Penelitian sebelumnya menyatakan bahwa pekerja dengan postur punggung tidak normal pada saat bekerja mempunyai risiko 2,5 kali lebih tinggi mengalami low back pain di bandingkan dengan pekerja yang postur punggung normal pada saat bekerja (Syuhada $\mathrm{AD}, 2018)$.

Masa kerja merupakan salah satu faktor yang dapat mempengaruhi kelelahan hal ini dikarenakan lamanya bekerja akan berpengaruh terhadap mekanisme dalam tubuh. Apabila masa kerja $>5$ tahun maka akan mempercepat konstraksi otot, dengan arti lain ada pengaruh yang signifikan antara masa kerja dengan kelelahan kerja. Seseorang yang memiliki masa kerja lebih lama memiliki pengalaman dan lebih memahami pekerjaannya sehari-hari daripada seseorang yang masa kerjanya baru sebentar (Atiqoh, 2014). Berdasarkan tabel, pekerja dengan masa kerja $>5$ tahun mengalami kelelahan kerja kategori berat sebanyak 31 orang $(63,3 \%)$ dan dapat disimpulkan bahwa ada hubungan antara masa kerja dengan kelelahan kerja.

Penelitian ini sesuai dengan penelitian pada pekerja Unit Pengerolan Besi PT.X dimana menunjukkan terdapat hubungan antara masa kerja dengan kelelahan kerja, dimana pekerja mengalami kelelahan memiliki masa kerja diatas 5 tahun. Hal tersebut bisa terjadi karena umur pekerja berkorelasi terhadap masa kerja, dimana semakin tua umur pekerja berarti pekerja tersebut memilki masa kerja lebih lama (Amalia I, 2019).

Selain itu terdapat penelitian dahulu yang menunjukkan bahwa tidak ada hubungan antara masa kerja dengan kelelahan kerja pada pekerja Workshop di PT. X dengan rata-rata masa kerja responden adalah 6 tahun. Masa kerja memiliki dampak positif dan negatif terhadap kinerja (Prasasti E, 2013). Dampak positif tersebut berupa seiring bertambahnya masa kerja maka pengalaman dalam bekerja semakin bertambah. Dampak negatifnya adalah semakin lama masa kerja maka semakin bertambah paparan bahaya yang diterima pekerja baik itu karena lingkungan kerja maupun hal lainnya (Bongakaraeng, 2019). Agar dapat mengurangi pekerja melakukan pekerjaannya dengan postur yang janggal maka pengelola dapat membuat desain kerja yang ergonomis dab melakukan peregangan untuk meregangkan otot. Karena dengan melakukan peregangan, otot-otot yang kaku bisa rileks kembali.

\section{PENUTUP}

Kesimpulan dari penelitian ini adalah terdapat hubungan signifikan antara iklim kerja (nilai $p=0,041$ ) postur kerja (nilai $p=0,027$ ), dan masa kerja (nilai $p=0,000$ ) dengan kelelahan kerja pada pekerja bengkel las di Lingkungan Getap Barat Kota Mataram.

Saran bagi pengelola untuk meminimalisir terjadinya kelelahan adalah dengan pembuatan desain kerja yang ergonomis, melakukan peregangan setiap satu jam sekali untuk meregangkan otot, selain itu bisa dengan penyediaan air minum di dekat pekerja melakukan pekerjaannya. Pekerja juga dapat menyampaikan aspirasi dan menerima edukasi terkait $\mathrm{K} 3$ melalui safety morning talk yang diselenggarakan pengelola. Bagi peneliti lain diharapkan dapat melakukan penelitian dengan variabel yang lebih banyak.

\section{DAFTAR PUSTAKA}

Amalia, I \& Widajati N. 2019. Analisa Kelelahan Kerja secara Obyektif Berdasarkan Reaction Timer pada Tenaga Kerja Unit Pengerolan Besi PT. X. Journal of Health Science and Prevention. 3(1):16-24

Amalia, N.R., Wahyuni, I. and Ekawati, E., 2017. Hubungan Postur Kerja dengan Keluhan Kelelahan Kerja pada Operator Container Crane PT. Terminal Peti Kemas Semarang. Jurnal Kesehatan Masyarakat (e-Journal). 5(5):290-298.

Atiqoh, J., Wahyuni,I., Lestantyo,D. 2014. FaktorFaktor Yang Berhubungan Dengan Kelelahan Kerja Pada Pekerja Konveksi Bagian Penjahitan di CV. Aneka Garment 
Gunungpati Semarang. J Kesehat Masy Univ Diponegoro, 2(2):119-26

Bongakaraeng. 2019. Relationship between Age, Working Period, and Work Duration with Fatigue on Pedycah Drivers in North kotamobagu District, North Sulawesi Indonesia. International Journal of Pharma and Biological Sciences, 8(3): 91-95

Guyton. Fisiologi Manusia dan Mekanisme Penyakit. 1994. Edisi ke-7. Jakarta: EGC

Hockey R. 2013. The Psychology of Fatigue Work, Effort and Control. New York: Cambridge University Press

International Labour Organization (ILO). 2013. The Prevent of Occupational Diseases. Geneva: International Labour Organization.

Kartika M. 2014. Analisis Paparan Iklim Kerja Panas terhadap Kelelahan, Beban Kerja dan Upaya Pengendalian. Jurnal Ikesma. 10: 115-129

Prasasti, E., 2013. Faktor-Faktor Yang Berhubungan Dengan Tingkat Kelelahan Kerja Pada Pekerja Workshop Di PT. X Jakarta Tahun 2013.

Setyaningsih, Y. 2018. Higiene Lingkungan Industri. Semarang: FKM Undip Press
Soeripto. 2008. Higien Industri. Jakarta: Balai Penerbit FKUI

Starizky, O., Ekawati, E. and Jayanti, S., 2016. Hubungan Antara Beban Kerja Dan Iklim Kerja Dengan Kelelahan Kerja Pada Pekerjaan Pengukuran Tanah Menggunakan Alat Teodolit. Jurnal Kesehatan Masyarakat (eJournal). 4(3):549-556.

Sulaiman, F. and Sari, Y.P., 2018. Analisis Postur Kerja Pekerja Proses Pengeasahan Batu Akik Dengan Menggunakan Metode Reba. Jurnal Optimalisasi. 1(1)

Susihono W. 2012. Perbaikan Postur Kerja untuk Mengurangi Keluhan Musculoskeletal dengan Pendekatan Metode OWAS. J Teknik IndustriSpektrum Industri. 10(1): 69-81

Syuhada, A.D., Suwondo, A. and Setyaningsih, Y., 2018. Faktor Risiko Low Back Pain pada Pekerja Pemetik Teh di Perkebunan Teh Ciater Kabupaten Subang. Jurnal Promosi Kesehatan Indonesia. 13(1):91-100

Tarwaka. 2010. Ergonomi Industri: Dasar-dasar Pengetahuan Ergonomi dan Aplikasi di Tempat Kerja. Solo: Harapan Press 